\title{
引張り亀裂を有する斜面の全体安全率の計算
}

\section{Calculations of Total Safety Factor of Slopes with Tension Cracks}

\author{
鵜 飼 恵 三* \\ Keizo UGAI
}

\begin{abstract}
This paper introduces a method for calculations of minimum total safety factors of slopes by means of the elasto-plastic FEM, considering tension cracks. Soils are assumed as elasto-plastic materials which obey the Mohr-Coulomb equation as the yield condition (or failure condition) and the Drucker-Prager equation as the flow rule.

The procedure of calculations is as follows. First, the shear strength of soils is assumed as $\tau_{f}=c^{\prime} / F+\sigma^{\prime}$ $\tan \phi^{\prime} / F$. The initial value of $\mathrm{F}$ is taken so small that the initial state of a slope is almost elastic. Next the value of $\mathrm{F}$ is increased step by step, and finally the ultimate value of $\mathrm{F}$ where slope failure occurs, is determined as the minimum total safety factor of the slope. If large tensile stresses occur in the slope, the above procedure is repeated again after thin elements with small strength and low Young's modulus are inserted into the places where tension cracks are assumed to appear.

It is shown that the method presented here can take account of tension cracks as well as pore water pressures properly which always reduce the safety factor of slopes.
\end{abstract}

キーワード: 有限要素法, 塑性, 安全率, 斜面安定解析

\section{1.まえがき}

任意の地形形状，不均質な土質分布及び不規則な間隙 水圧分布を有する一般的な斜面の安全率を求める方法を 確立することは, 斜面安定解析法の進展という立場ばか りでなく，実務においても大変重要なことである。通常 斜面の安全率の計算は, 分割法のような極限平衡法にも とづいて行われるが，上記のような一般的な斜面の最小 安全率を求めることは，困難であることが多い。

一方, 最近, 電算機と FEM (有限要素法) の発達に伴 い, 斜面の安定問題を弾塑性 FEM により解明しようと する試みが盛んになってきた。FEM は応力状態のみな らず変形状態も表現できること, 局所的な破壊現象を把 えることができるなど，斜面の安定性を実態に即した形 で表現できる。しかし，FEM で計算される安全率は一般 に局所安全率であり，分割法などで計算される全体安全 率との関係が明瞭ではなかった。この点を克服するため に筆者はZienkiewicz ら1) の方法を発展させ, 弾塑性 FEM にもとづいて斜面の全体安全率を計算する方法を 提案してきた2),3)。最近, この方法をさらに進展させ, 引 張り亀裂をも考慮できるようにしたので，ここに報告を 行う。

* 群馬大学工学部建設工学科

\section{2. 本方法と極限平衡法から計算される安全率 の類似点と相違点}

本報告で提示される方法により算出される安全率は全 体安全率であり, 極限平衡法（分割法など）功得られ る安全率と同じ意味をもつ。このことを説明するために， まず從来の極限平衡法によって斜面の安全率を求める手 順を復習してみよう。

極限平衡法では, 土のせん断強度 $\tau_{f}$ は

$$
\tau_{f}=c^{\prime}+\sigma^{\prime} \tan \phi^{\prime}
$$

で表せるとする。ここで， $c^{\prime}$ と $\phi^{\prime}$ は有効応力に関する土 の粘着力と摩擦角であり， $\sigma^{\prime}$ は想定されたすべり面上の 有効垂直応力である。斜面内に，あるすべり面を想定し， すべり面上のせん断応力 $\tau$ が

$$
\begin{aligned}
\tau & =\tau_{f} / F_{s} \\
& =c^{\prime} / F_{s}+\sigma^{\prime} \tan \phi^{\prime} / F_{s}
\end{aligned}
$$

で表せるとする。 $\sigma^{\prime}$ の大きさは，たとえば分割法では， 分割片に作用するいくつかの力のつり合いより決定する。 こののち, すべり土塊全体の力のつり合い式もしくは モーメントのつり合い式を立て, これから未知量 $F_{s}$ の值 を決定し，これを対応するすべり面に関する斜面の安全 率と定義する。さらに, 最小安全率を求めるためには, 多数のすべり面を想定した上で安全率を計算し, それら の中から最小值を見い出す必要がある。すでに示したよ 
うに4), 極限平衡法は, すべり土塊全体の力のつり合いと モーメントのつり合いをすべて満たすとは限らない。た とえば簡便法 (Fellenius 法) はモーメントのつり合いは 満たすが, 力のつり合いは満たさない。従って,このよ うな方法から計算される安全率には, おのずから精度の 限界がある。一方, 本報告で提示する弾塑性 FEM にもと づく方法では, 式(1)と式(2)はもちろんのこと, すべり土 塊のみならず有限要素に作用する力とモーメントのつり 合いが, FEM の精度の範囲内であるが, 完全に満たされ る。そして最小安全率も同時に得られ, すべり領域ある いはすべり面も確定する。

\section{3. 本計算法の概要}

地盤は 2 次元平面歪状態であるとし, 弾完全塑性の性 質を示すとする。土の破壊条件として Mohr-Coulomb 式（式(1)もしくは式(3)), 塑性ポテンシャルとして, Drucker-Prager 式（式(4)）を仮定する。これらを xy座 標系での応力成分 $\sigma^{\prime}{ }_{x}, \sigma^{\prime}{ }_{y}, \tau_{x y}$ により表現すると, 各々

$$
\begin{aligned}
& f \equiv-\left(\sigma^{\prime}{ }_{x}+\sigma^{\prime}{ }_{y}\right) / 2 \cdot \sin \phi^{\prime} \\
& +\sqrt{\left(\sigma_{x}^{\prime}-\sigma_{y}^{\prime}\right)^{2} / 4+\tau_{x y}^{2}}-c^{\prime} \cos \phi^{\prime} \\
& =0 \\
& \Phi=-\left(\sigma_{x}^{\prime}+\sigma_{y}^{\prime}\right) / 2 \cdot \sin \psi \\
& +\sqrt{\left(\sigma_{x}^{\prime}-\sigma_{y}^{\prime}\right)^{2} / 4+\tau_{x y}^{2}}-c^{\prime} \cos \psi
\end{aligned}
$$

となる。 $\psi$ はダイレイタンシー角である。これまでの研究 から, $\psi$ が大きいほど斜面の安全率は大きくなるが, その 影響はそれほど大きくないことがわかっている。土が破 壊状態にあるとき，体積変化はゼロに近いと考えられる

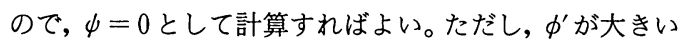
砂地盤では

$$
\phi=\phi^{\prime}-\phi_{c r i f}^{\prime}
$$

とすると, 砂の要素試験結果と近似的に符合する ${ }^{5)}$ ここ で $\phi_{c r i f}^{\prime}$ は, 同じ砂の非常にゆるい状態での $\phi^{\prime}$ の值であ る。弾塑性 FEM の定式化に際して必要になる応力増分 $\boldsymbol{d} \boldsymbol{\sigma}^{T}=\left(\begin{array}{lll}d \sigma_{x} & d \sigma_{y} & d \tau_{x y}\end{array}\right)$ と全歪增分 $\boldsymbol{d} \boldsymbol{\varepsilon}^{T}=\left(\begin{array}{ll}d \varepsilon_{x} & d \varepsilon_{y}\end{array}\right.$ $\left.d \gamma_{x y}\right)$ との関係は次のようになる ${ }^{6)}$ 。ここで, 添字 $T$ は, 行と列の置き換え（転置）を表す。

$$
\begin{aligned}
& \boldsymbol{d} \boldsymbol{\sigma}=\left[D^{e}-(1-r) \frac{D^{e}\{\partial \Phi / \partial \sigma\}\{\partial f / \partial \sigma\}^{T} D^{e}}{\{\partial f / \partial \sigma\}^{T} D^{e}\{\partial \Phi / \partial \sigma\}}\right] \\
& d \varepsilon
\end{aligned}
$$

ここで, $D^{e}$ は弾性係数マトリクスである。

$$
\begin{aligned}
& D^{e}=\frac{E}{2(1+\nu)} \\
& {\left[\begin{array}{ccc}
2(1-\nu) /(1-2 \nu) & 2 \nu /(1-2 \nu) & 0 \\
2 \nu /(1-2 \nu) & 2(1-\nu) /(1-2 \nu) & 0 \\
0 & 0 & 1
\end{array}\right] \cdots(7)}
\end{aligned}
$$

と表せる。 $E$ とンは, 土のヤング係数とポアソン比であ る。 $E$ と $\nu$ のきさは, 斜面の安全率の計算結果に大き
な影響を与えないことが，これまでの計算例からわかっ ている。式(6)で \{ \} は列ベクトルを表し, たとえば

$\{\partial \Phi / \partial \sigma\}^{T}=\left(\partial \Phi / \partial \sigma_{x} \partial \Phi / \partial \sigma_{y} \partial \Phi / \partial \tau_{x y}\right) \cdots \cdots(8)$ である。地盤が弾性変形をするときは, 式(6)で $r=1$ とお く。完全な弾塑性状態では $r=0$ とする。弾性状態から弾 塑性状態へと移行する場合には， $0<r<1$ であり，rの 値は文献 6)などに示される方法から決定する。以上の仮 定によれば, 均一な地盤の土質定数は， $E ， \nu, c^{\prime}, \phi^{\prime}$, 隹び $\gamma$ 六つのパラメータによって表現されることに なる。

計算の具体的な方法を説明しよう。図ー1(a)のような 斜面の安全率を計算するために, 8 節点 4 辺形アイソパ ラメトリック要素を用いてメッシュ分割する。ある要素 の中の一つのガウス点 $\mathrm{A}$ に着目する。土のせん断強度 $\tau_{f}$ は

$$
\tau_{f}=c^{\prime}+\sigma^{\prime} \tan \phi^{\prime}
$$

で表せるとする。今，仮想的に土のせん断強度が式(1)を 係数 $F$ で割った形で表せると仮定しよう。すなわち

$$
\tau_{F}=c^{\prime} / F+\sigma^{\prime} \tan \phi^{\prime} / F
$$

最初 $F$ の值を小さくとると, 仮想的なせん断強度 $\tau_{F}$ は大 きくなるので, 点 Aでの応力状態は弾性状態になる (図一 $1(\mathrm{~b}))$ 。次に $F$ を段階的に大きくしていくと，ある $F$ の值 のとき，式(9)はA点でのモール応力円と交差するように なる図ー1(c)。このような応力状態は存在しえないので, 図ー1 (c)の破線の円で示すようにモール円が仮想的なせ ん断強度線に接するよう応力補正を行う。さらに $F$ を増 加させて計算を行い, ある段階での弾塑性 FEM の反復 計算が発散し斜面が崩壊に至ったと判断されたときの $F$ の值を斜面の（全体）安全率と定義する。

\section{4. 間隙水圧と引張り竜裂の考慮の仕方}

斜面内の間隙水圧（静水圧, 透水による水圧, 盛土内 での過剰間吵水圧）の分布と大きさは，与えられるもの とする。これを FEM 計算に組み込む方法は,すでに文献 3）などで説明したが, それは 3 節点 3 角形要素 (要素内 で応力と歪が一定）に対するものであった。本報告では 8 節点 4 辺形アイソパラメトリック要素と有限要素とし て用いているので, その場合の間隙水圧の考虑の仕方を 説明する。

図-2 に示す要素の四つの頂点の番号を I , J , K, L とし, 各節点位置での水圧を $\mathrm{p}(\mathrm{I}), \cdots \cdots, \mathrm{p}(\mathrm{L})$ とす る。四つの辺上では水圧は直線分布であると仮定し, 各 辺上の全水圧を計算する。そして，これらの水圧の合力 を計算する。次にこの合水圧は，要素に作用する一様な 物体力から生じたものであると仮定し，等価節点力に換 算する。そしてこの等価節点力を，各節点に合水圧と同 じ方向に作用させる。このようにして水圧を等価節点力 


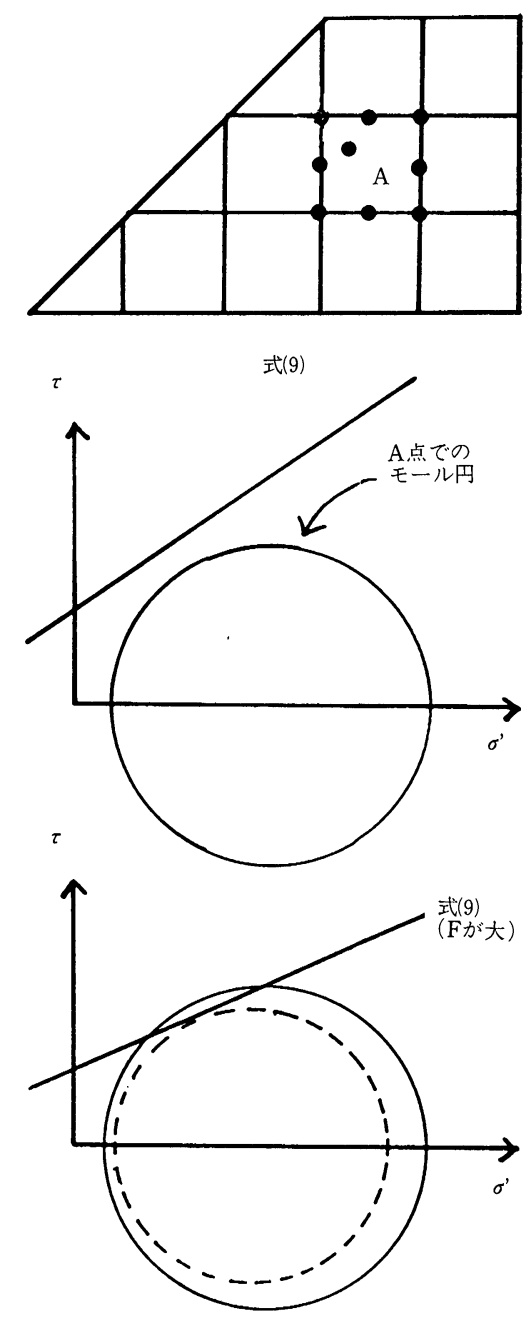

図ー1＼cjkstart計算の方法を説明するための図

に置き換えた。以上の仮定が正しいかどうかをチェック するために，ある斜面で，完全水没のケースと，非水没 で水中重量を用いたケースの計算結果を比較したところ 安全率やせん断歪分布などが完全に一致することがわ かった。

次に, 引張り亀裂の考慮の仕方を説明する。引張り亀 裂が斜面上部に予測されるときには，図－3のように鉛 直方向に何䉪所か薄い要素をはさんでおく。このような メッシュ分割のもとで，まず引張り亀裂を考慮しない弾 塑性 FEM 計算を行い, 斜面のすべり破壊状態における 応力分布を求める。このとき，挿入されている薄い要素 のうち, 引張り応力が作用しているものをピックアップ する。次に，引張り亀裂を考慮した解析を行う。その方 法は, 以前と同じメッシュ分割で, 引張り応力の作用し た薄い要素の強度定数を他の要素よりもかなり小さくし， かつヤング係数も小さくする。また自重はゼロにしてし

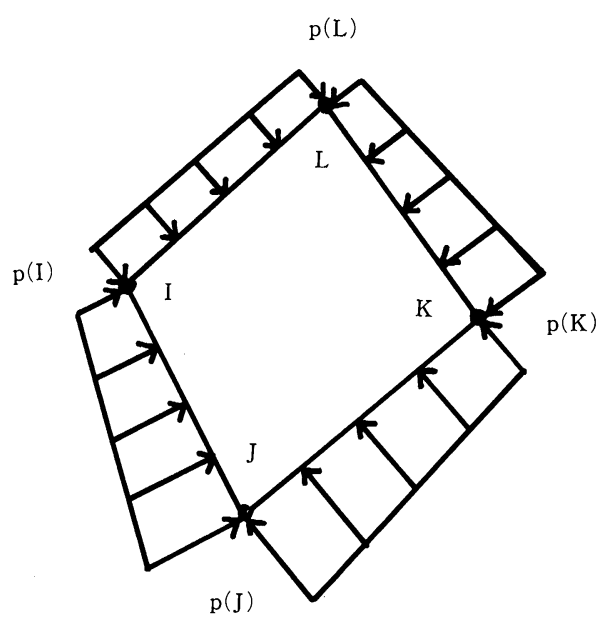

図一2 4 辺形要素に作用する水圧

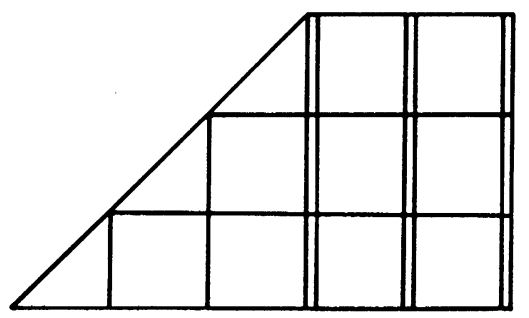

図ー3 引張り亀裂を考慮するためのメッシュ分割の例

まう。そして再び弾塑性 FEM 計算を行い, 斜面の破壊状 態を求め, 応力分布を決定する。このとき, 斜面上部の 要素内に大きな引張り応力が生じていなければ, その結 果を引張り亀裂を考慮した正しい解析結果と考える。安 全率の值は, 引張り亀裂を考慮したときの方が当然小さ くなる。

\section{5. 計算例}

図一4(a)に示す斜面を対象にして計算の具体的な方法 と計算結果を示す。斜面の高さは $10 \mathrm{~m}$, 勾配は $45^{\circ}$ であ る。土質定数は次のようである。 $E=20000 \mathrm{tf} / \mathrm{m}^{2}, \nu=$ $0.25, c=2 \mathrm{tf} / \mathrm{m}^{2}, \phi=20^{\circ}, \phi=0^{\circ}, \gamma=2 \mathrm{tf} / \mathrm{m}^{3}$ 。

\section{1 引張り电裂を考慮しないケース}

図一5(a)に弾塑性 FEM による結果を示す。図中には 斜面崩壊直前の最大せん弾歪速度 $\dot{\gamma}_{m}$ (相対值) の分布図 が示されている。安全率は 1.26 となった。簡便分割法と

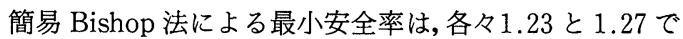
あり，弾塑性 FEMによる值とほほ一致する。また，これ らの分割法によるすべり面の位置も，図一5(a)に示され るすべり領域内にほほ収まることが確認された。

同じ斜面で間隙水圧を考慮した解析を行った。斜面内 


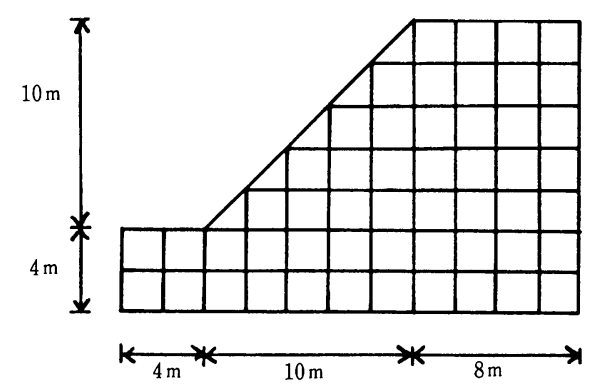

(a)

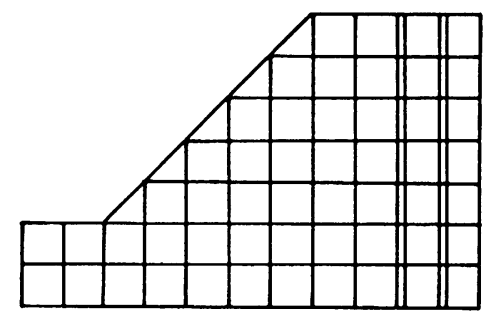

图ー4 計算例に用いた斜面とメッシュ分割

の間隙水圧は

$u=r_{u} \gamma h$

で表せるとした。 $r_{u}$ は間隙水圧係数と呼ばれ，その位置 での間吵水圧と土被り圧との比を表わす。 $h$ は斜面の表 面からの深さである。図ー5(b)に崩壊直前の $\dot{\gamma}_{m}$ の分布図 を示す。弾塑性 FEM による安全率は 1.03 になった。簡 便分割法と簡易 Bishop 法による最小安全率は 1.00 と 1.05 であり，ほほ一致する。すべり面の位置もほほ同様 であることがわかった。

以上より，均質な単純斜面で，間隙水圧が大きくない 場合には, 本報告で述べる弾塑性 FEM から得られる安 全率の值と, 代表的な分割計算法から得られる最小安全 率の值はほほ一致し,すべり面形状も同様となることが 確認された。

\section{2 引張り暒裂を考虑するケース}

図一 5 (a)，(b)に示される斜面の崩壊直前の応力状態を 調べると, 斜面の上部に水平方向の引張り応力が生じて いることが確認された。たとえば図一5(a)のケースでは, 図一6に示される斜線部に引張応力が生じていた。そこ で，このような引張応力を低減させるために $\mathrm{AB}$ 線部と $\mathrm{CD}$ 線部を含む幅 $5 \mathrm{~cm}$ の薄い要素を図ー4(b)のように 配置した上で, $\mathrm{AB}$ と $\mathrm{CD}$ 部の土質定数を次のように変 えた。

$$
\begin{aligned}
& E=200 \mathrm{tf} / \mathrm{m}^{2}, \nu=0, c=0.02 \mathrm{tf} / \mathrm{m}^{2}, \phi=0^{\circ}, \\
& \phi=0^{\circ}, \quad \gamma=0 \mathrm{tf} / \mathrm{m}^{3}
\end{aligned}
$$

すなわち, 引張り亀裂を考虑するために，その部分に伸 張性が良く強度と自重の小さい要素をそう入した。図一 7 に崩壊直前の $\dot{\gamma}_{m}$ の分布図を示す。この図より, 鉛直線
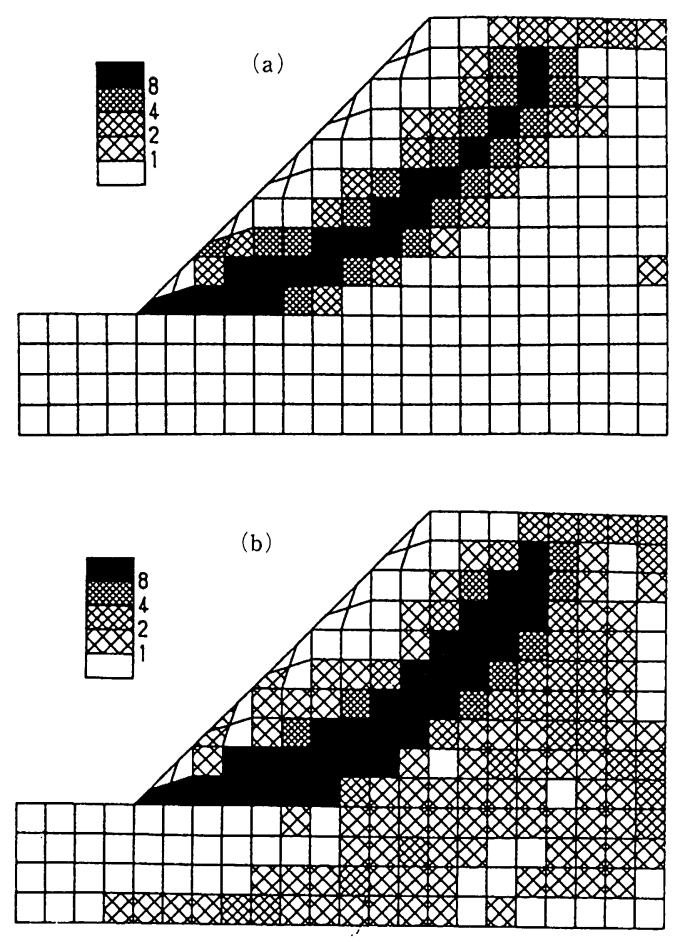

図-5 崩壊直前の最大せん断歪速度 $\dot{\gamma}_{m}$ （相対値）の分布 (a) $r_{u}=0$, (b) $r_{u}=0.5$

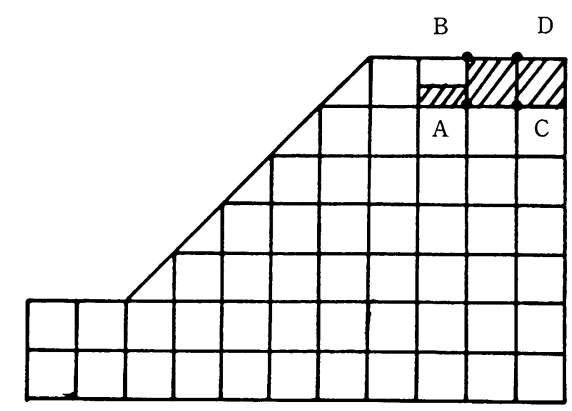

図ー6 図ー5(a)のケースにおける引張り応力発生個所 (斜線部)

BA 図一6に沿って深さ $2 \mathrm{~m}$ の亀裂が発生し，亀裂下端 よりすべり領域が始まっている様子がうかがえる。図一 6 において斜面上部に存在した引張り応力は図一 -7 にお いては $1 / 5$ 以下に低減していることがわかった。また， 斜面の安全率は 1.24 となり,龟裂を考慮しないケースに 比べ 0.02 低下した。引張り亀裂を考慮した効果をより明 瞭に示すために，図一6の DC を通る鉛直線上の水平応 力 $\sigma_{x}$ の分布を示したのが図ー8 (a), (b)である。図ー8より 斜面上部に発生していた引張応力が, 引張り亀裂を考慮 することによりほほゼロになっているのがわかる。

図-9 は $r_{u}=0.5$ のケースで, 引き張り亀裂を考慮し た場合の崩壊直前の $\dot{\gamma}_{m}$ の分布図である。引張り亀裂は, 


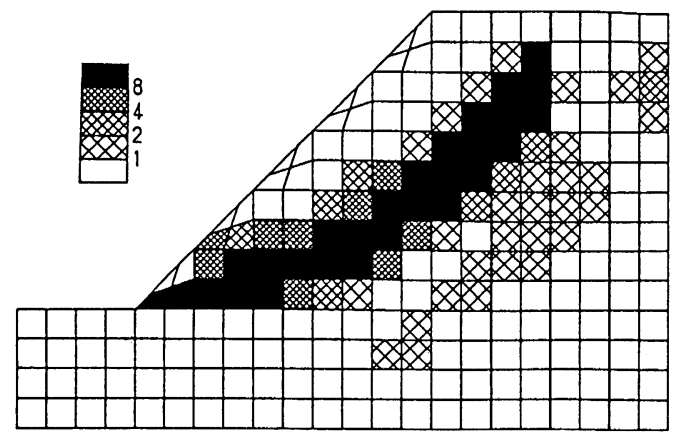

図ー7 引張り亀裂を考慮したときの崩壊直前の $\dot{\gamma}_{m}$ (相対值) の分布 $\left(r_{u}=0\right)$

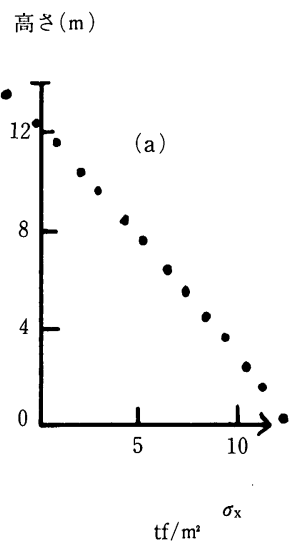

高さ $(\mathrm{m})$

図一8 DC (図一6) を含む鉛直線上の $\sigma_{x}$ 分布 (a)引っ張り亀裂を考慮しないケース (b)考慮したケース

図ー6 の点 $\mathrm{B}$ と $\mathrm{D}$ から $4 \mathrm{~m}$ の深さまで達するとして計算 を行った。この際，浮力により上方向の荷重が発生しな いよう, 亀裂部の薄い要素の単位体積重量を $1 \mathrm{tf} / \mathrm{m}^{3}$ に した。斜面の安全率は 1.01 となり, 龟裂を考慮しない ケースに比べ 0.02 低下した。図一 6 の BA を通る鉛直線 上の水平応力 $\sigma_{x}$ の分布を示したのが図 $-10(\mathrm{a})$ ，(b)であ る。斜面上部に発生していた引張応力が, 引張り亀裂を 考慮することによりほほゼロになっているがわかる。

\section{6. あとがき}

本報告では，通常用いられる弾塑性 FEM に工夫を加 えて, 斜面の全体安全率を計算する方法を示した。そし て,しばしば見られる斜面肩付近の引張り亀裂を考慮す る方法を提示した。弾塑性 FEM を用いて斜面崩壊の解 析を行う事例は今後さらに増加してゆくものと思われる が，従来の慣用的な弾塑性 FEM 手法のみにとらわれず， それに色々な工夫を加えて安定解析を試みることがます ます必要となるであろう7。

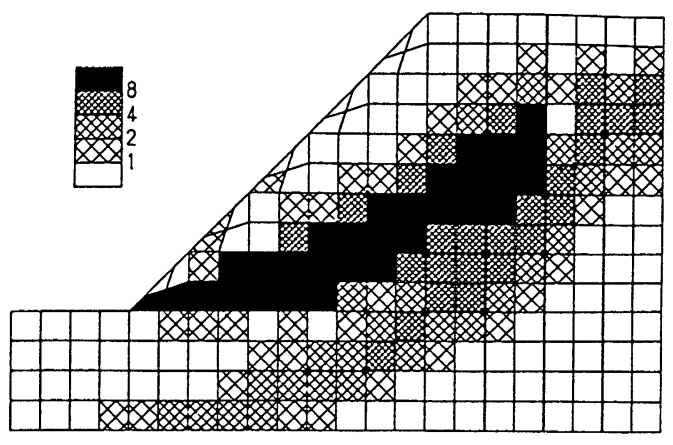

図ー9 引張り亀裂を考慮したときの崩壊直前の $\dot{\gamma}_{m}$ (相対值) の分布 $\left(r_{u}=0.5\right)$

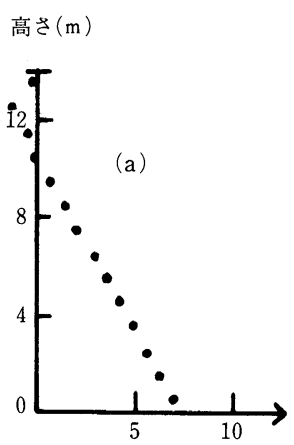

高さ $(\mathrm{m})$

$\mathrm{tf} / \mathrm{m}^{2} \quad \sigma_{\mathrm{x}}$

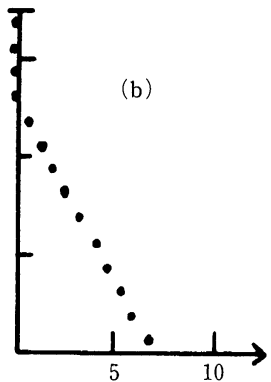

$\mathrm{tf} / \mathrm{m}^{2} \quad \sigma_{\mathrm{x}}$

図一10 BA（図一）を含む鉛直線上の $\sigma_{x}$ の分布 (a)引張り亀裂を考慮しないケース (b)考慮したケース

本計算で用いた弾塑性 FEM プログラムは 700 行程度 である。読者の中で必要とされる方がおられれば,コピー を差し上げる。筆者まで申し込まれたい。

\section{参考文献}

1) Zienkiewicz, O. C., Humpheson, C. and Lewis, R. W.: Associated and Non-associated Viscoplasticity and Plasticity in Soil Mechanics, Geotechnique, 25-4, pp. $671-689,1975$.

2 ) 鵜飼恵三: 弾塑性 FEM による斜面の全体安全率の計算 法, 土質工学会論文報告集, 29-2, pp. 190-195, 1989.

3 ) 鵜飼恵三: 安定解析におけるせん断強度低減法の有用性, 土と基礎，38-1，pp. 67-72，1990.

4 ) 鵜飼恵三: 分割法による斜面の三次元安定性の検討, 土 と基礎，36-5，pp. 19-24，1988.

5 ) Bolton, M. D.: The strength and dilatancy of sands, Geotechnique, 36-1, pp. 65-78, 1986.

6) 田中忠次:「土質力学における数值解析」，わかりやすい 土質力学原論, 土質工学会, pp. 203-243, 1987.

7 ) 藤田寿雄・吉松弘行・白石一夫: 地すべり対策杭の挙動と 有限要素法による解析，地すべり，24-3，pp. 15-22， 1987.

（原稿受理日 平成 3 年 10 月 21 日） 